
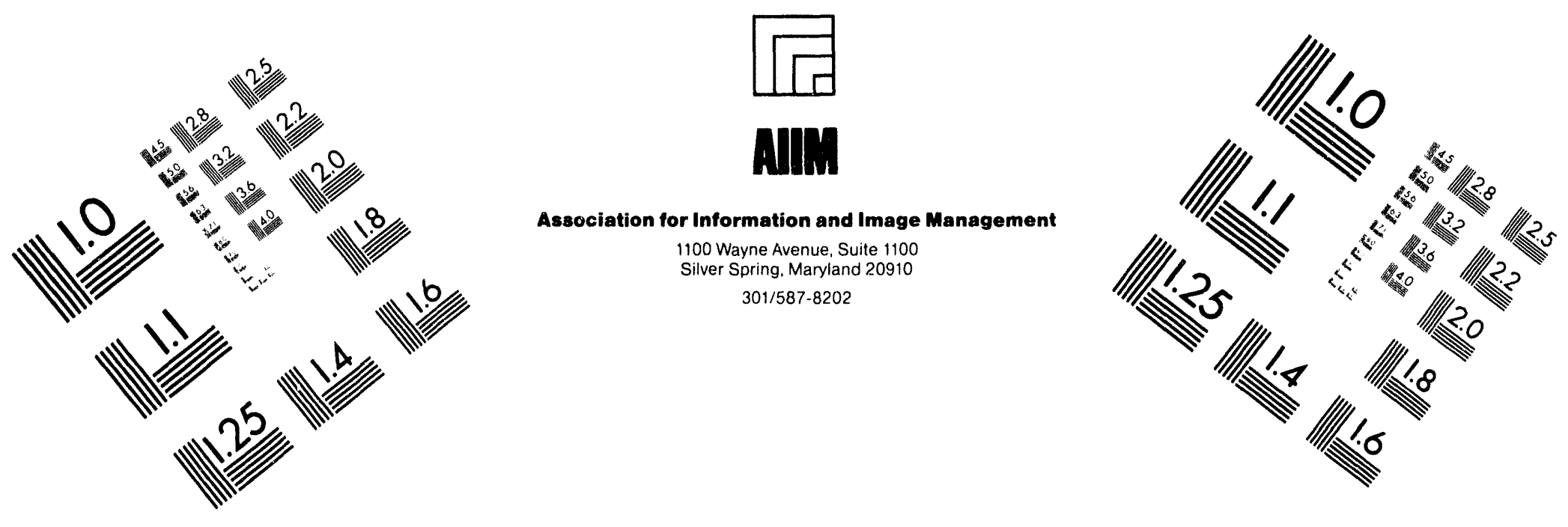

Centimeter

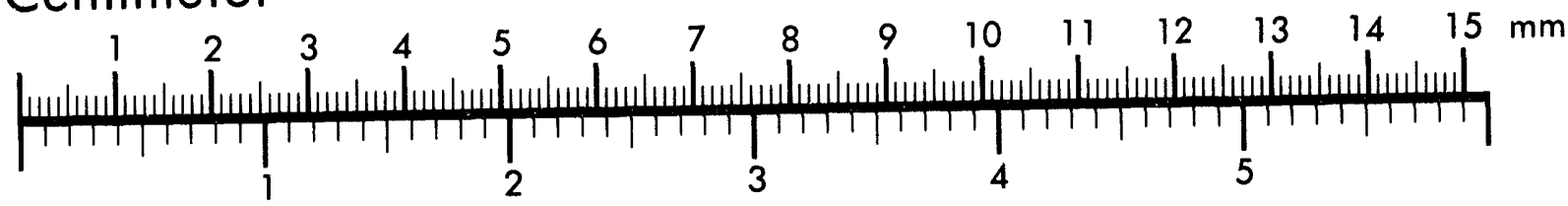
Inches
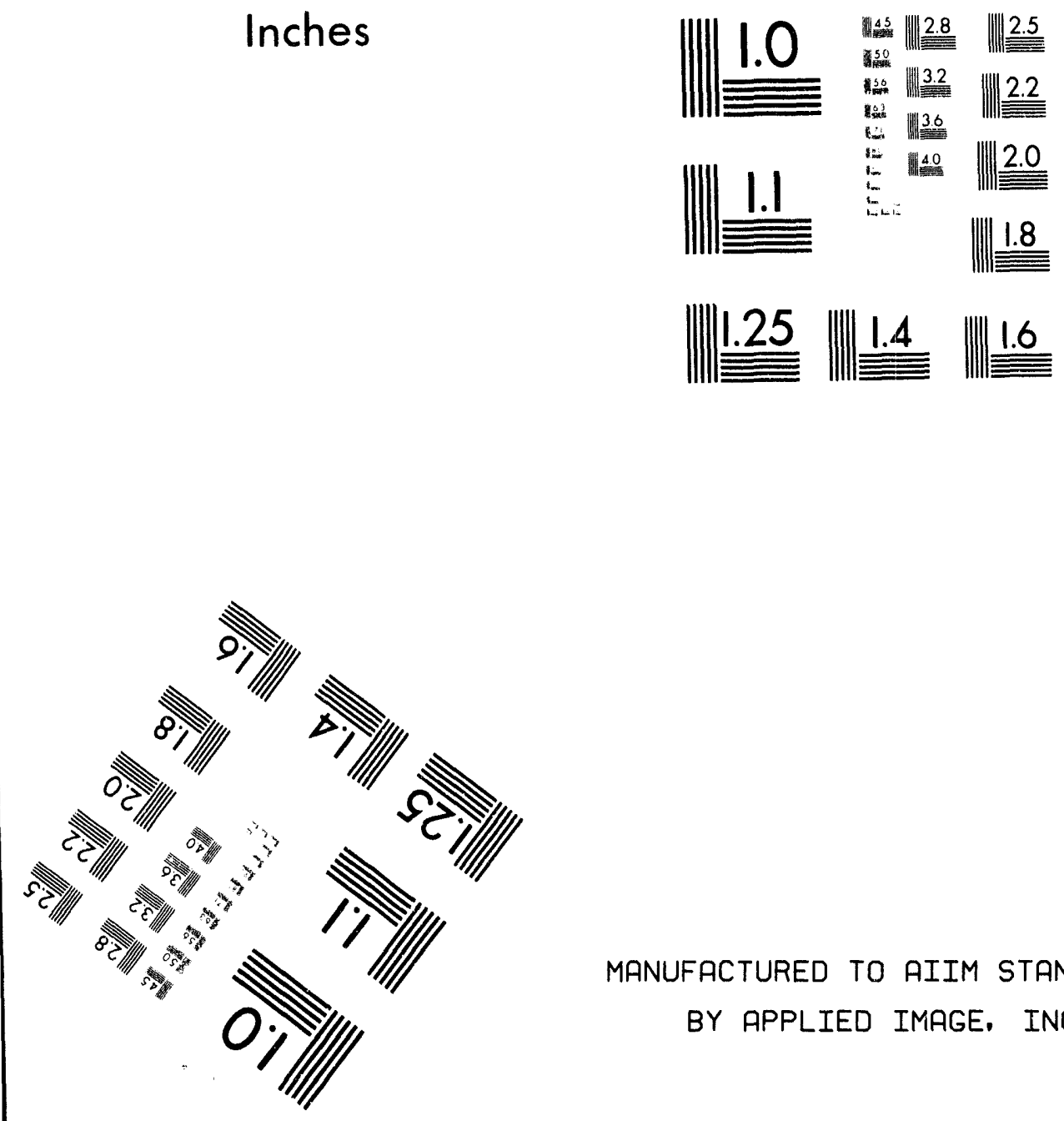

MANUFACTURED TO AIIM STANDARDS BY APPLIED IMAGE, INC.

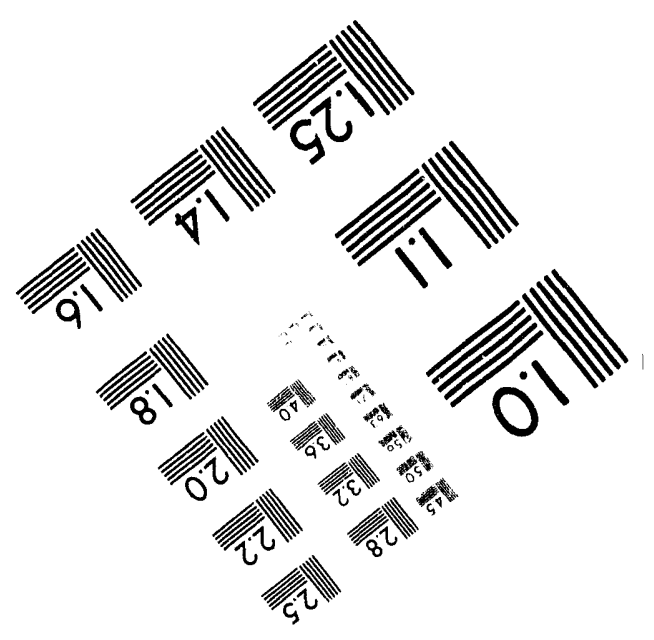



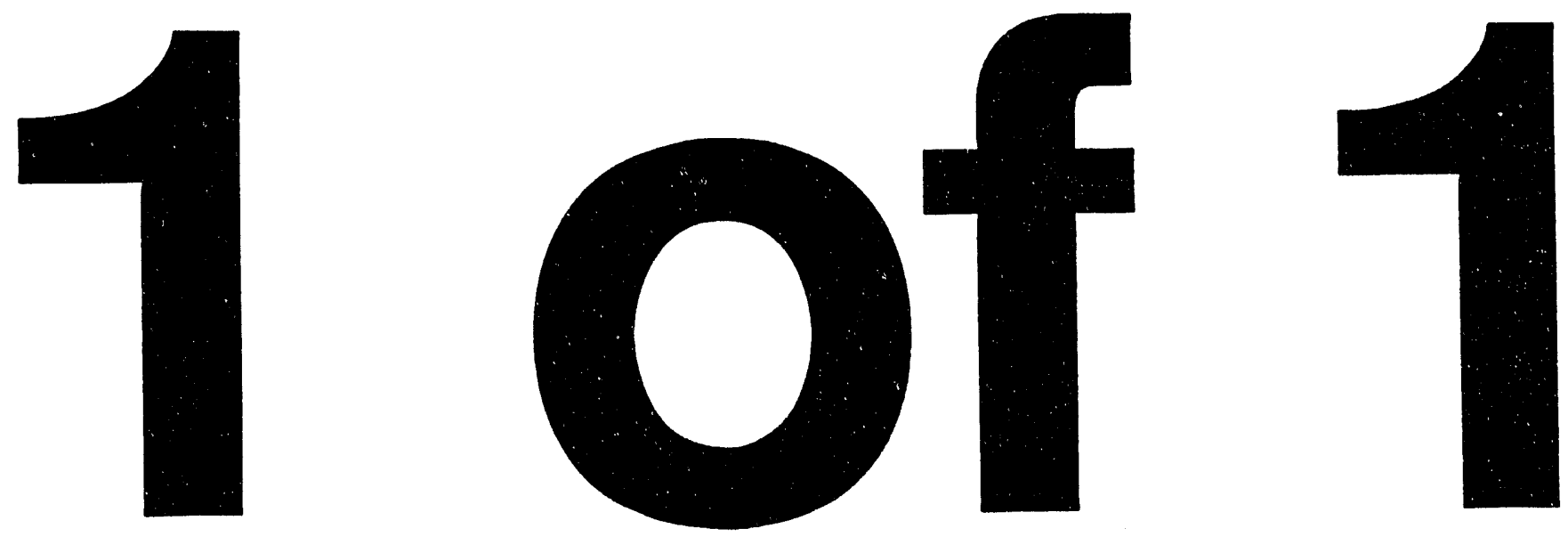


\title{
FEASIBILTY ASSESSMENT OF LOW TEMPERATURE VOLTAIC ENERGY CONVERSION
}

\author{
PF Baldasaro, BC Campbell, \\ DM Depoy, J. Parrington
}

April 1994

\section{Prepared for}

The United States Department of Energy

Prepared by

Knolls Atomic Power Laboratory

P. O. Box 1072

Schenectady, New York

Contract No. DE-AC12-76-SN00052

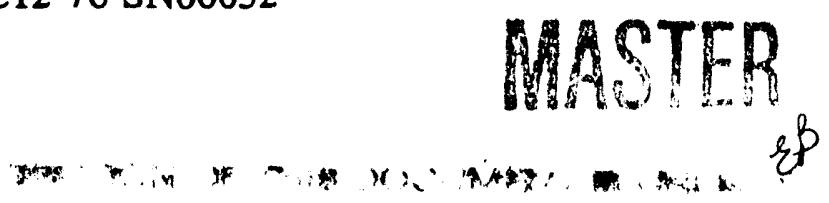




\section{DISCLAIMER}

This report was prepared as an account of work sponsored by an agency of the United States Government. Neither the United States Government nor any agency thereof, nor any of their employees, makes any warranty, express or implied, or assumes any legal liability or responsibility for the accuracy, completeness, or usefulness of any information, apparatus, product, or process disclosed, or represents that its use would not infringe privately owned rights. Reference herein to any specific commercial product, process, or service by trade name, trademark, manufacturer, or otherwise, does not necessarily constitute or imply its endorsement, recommendation, or favoring by the United States Government or any agency thereof. The views and opinions of authors expressed herein do not necessarily state or reflect those of the United States Government or any agency thereof. 


\section{TABLE OF CONTENTS}

$\begin{array}{lll}\text { I } & \text { Introduction } & \text { Page } \\ \text { II } & \text { Analysis Results } & 1 \\ \text { III } & \text { Experimental Results } & 1 \\ \text { IV } & \text { Summary } & 2 \\ & \text { References } & 4 \\ & & 5\end{array}$

Figure No.

Figure Title

1

2

3

4

5

6
Thermo Voltaic Concept 6

Predicted 900C Voltaic Cell Performance 7

Predicted TV Performance vs Dark Current 8

Predicted TV Performance Sensitivity to Spectral Control 9

Measured IV Characteristics for InGaAs Cells $\quad 10$

Measured Efficiency and Power Density vs Emitter

Temperature
11

KAPL -4778 
An experimental and theoretical investigation of the feasibility of thermo voltaic (TV) power generation in the temperature range $800^{\circ} \mathrm{C}-1000^{\circ} \mathrm{C}$ has been performed. In this concept, voltaic celis of Indium-Galium-Arsenide (InGaAs) were employed to convert thermal radiation directly into electric power. The advantage of this concept over previous thermo photo voltaic concepts (TPV) is the reduced materials issues associated with a lower heat source temperature, and applicability to a wider range of fossil fuels.

A numerical model was constructed and used to analyze test data, demonstrating good agreement and understanding of process physics. The key functional parameters were found to be dark current coefficient and spectral efficiency. A conversion efficiency of $25 \%$ was measured at $900^{\circ} \mathrm{C}$, with potential for $30 \%$ in optimized devices. The limiting issue for a practical TV power converter below $900^{\circ} \mathrm{C}$ is the required power density, which is a strong function of heat source temperature. 


\section{FEASIBILITY ASSESSMENT OF LOW TEMPERATURE VOLTAIC ENERGY CONVERSION}

\section{Introduction}

The rapid progress being made in the design and fabrication technology of voltaic converters suggests application to lower temperature regimes where materials-related problems are more manageable, and where a wider range of fossil fuel heat sources may be employed. This paper addresses the feasibility of using voltaic cells to convert thermal radiation into electric power from temperatures as low as $800^{\circ} \mathrm{C}$. Because of the low spectral content of visible light at these temperatures, the conversion process in this temperature range is referred to as thermo voltaics (TV), rather than photo voltaic (PV) or thermo photo voltaics (TPV) as referred to in the literature ${ }^{(1,2,3)}$.

Figure 1 schematically describes the basic conversion process. An external energy source heats a static emitter which generates a thermal radiation spectrum. The thermal radiation is transmitted to voltaic cells which absorb the radiation and convert a fraction into useful electric power. Between the emitter and the voltaic cell is a spectral control device, with the function of minimizing the spectral content of below-bandgap (parasitic) thermal radiation reaching the voltaic cell. Generally there must be a partial vacuum between the emitter and the voltaic cell to minimize parasitic conduction and convection heat losses.

Previous similar work in the area of $\operatorname{TPV}^{(4,5,6,7)}$ has focused on temperatures $>1200^{\circ} \mathrm{C}$, for use in solar concentration, or higher temperature fossil fuel systems. For heat source temperatures below $1000^{\circ} \mathrm{C}$, achievable cell power density is much lower because of the strong temperature sensitivity of blackbody thermal emission

( $i . e$. the sefan-Boltzman $\mathrm{T}^{4}$ functionality). With low heat input fluxes, output power density becomes a controlling factor in device design, necessitating the use of lower bandgaps (< $0.6 \mathrm{ev}$ ) than typically employed in TPV or PV. For a practical power generator to operate in this temperature regime, every effort must be made to maximize the photon flux above the bandgap, while minimizing the photon flux below the bandgap.

\section{ANALYSIS RESULTS}

Because of the need for lower bandgaps at lower temperatures, dark current levels are much higher, and play a greater role in limiting overall efficiency than in higher temperature applications (by limiting achievable output voltage). In addition, the fraction of blackbody thermal radiation above the bandgap is low under these conditions (< $10 \%$ at $900^{\circ} \mathrm{C}$ for a $0.6 \mathrm{ev}$ bandgap). The low fraction of convertible thermal radiation magnifies the importance of high spectral control, i.e. the fraction of total energy absorbed by the voltaic cell that is above the bandgap must be high. prior to analysis and experiment it was expected therefore that the key process parameters would be dark current and spectral efficiency. 
Figure 2 shows predictions of efficiency and cell electric power density versus bandgap at $900^{\circ} \mathrm{C}$. These calculations were performed with extrapolations of solar cell dark current correlations obtained from the National Renewable Energy Lab (NREL). Also implicit in the Figure 2 calculations is the assumption that below-bandgap energy is only $10 \%$ of the total thermal energy absorbed by the cell, i.e. a controlled thermal radiation source with $90 \%$ spectral efficiency is assumed. For the application of interest, an area electric power density $>0.4 \mathrm{w} / \mathrm{cm}^{2}$ was required, which necessitated a bandgap below $0.6 \mathrm{ev}$.

Figure 3 shows the sensitivity of efficiency and power density to the dark current coefficient. A factor of $10 x$ in the dark current has approximately a $30 \%$ relative effect on efficiency and power density at a nominal bandgap of $0.6 \mathrm{ev}$. For nominal dark current values, efficiencies $>25 \%$ are predicted.

The sensitivity to spectral efficiency is shown in Figure 4, assuming a blackbody thermal emitter at $900^{\circ} \mathrm{C}$. Varying the belowbandgap absorption fraction from $10 \%$ to $50 \%$ changes predicted conversion efficiency from $25 \%$ to $14 \%$, demonstrating the strong sensitivity to the input thermal radiation spectrum and the importance of efficient spectral control. To achieve an overall efficiency goal of $20 \%$, the spectral efficiency must be $>70 \%$.

\section{EXPERIMENTAL RESULTS}

The voltaic cells employed in these experiments were developed by NREL, and the details of design are considered proprietary at this time, as is the specific spectral control technology. The cells have a grid cuverage (shadow loss) of approximately 15\%, and an active power producing area of $.075 \mathrm{~cm}^{2}$ per cell. Measurements were taken with both single cells and multiple-connected cells with similar results, i.e. little cell-to-cell, or cell coupling variation.

Reported efficiencies are calculated as the ratio of delivered electric power density to absorbed thermal radiation flux. Input thermal flux measurements were obtained with a calibrated pyroelectric radiometer. Output power was determined from cell current/voltage (IV) output traces obtained by varying the load resistance to find the maximum power point. The technique of using output to input flux ratios to calculate efficiency ignores the conduction and convection losses that would be present in an actual generator environment, and neglects reflection effects (less than $5 \%$ effects for both above-bandgap and below-bandgap wavelengths). These efficiencies represent the upper bound on achievable generator efficiency. 
Figure 5 presents a series of measured InGaAs cell IV curves for varying emitter temperature, with voltaic cell temperatures held below $30^{\circ} \mathrm{C}$. As pointed out previously, the key feasibility issue with low-bandgap cells was considered to be voltage generation. From the data in Figure 5 the achieved voltage factors (open circuit voltage divided by cell bandgap) are - 0.5, agreeing closely with predictions. It is to be noted that the maximum achievable voltage is thermodynamically limited to the carnot. efficiency times the cell bandgap ${ }^{(8)}$, which would be 0.48 volts for a $0.6 \mathrm{ev}$ bandgap with heat source temperature at $900^{\circ} \mathrm{C}$. These initial InGaAs cells therefore achieved roughly $62 \%$ of the maximum theoretical voltage.

Comparison of input power to output current indicates an integral quantum efficiency of approximately $80 \%$, which is a high value considering the unoptimized nature of these initial cells. Initial cell fabrication runs were made without detailed knowledge of optical absorption properties, and subsequent cells would be expected to have improved quantum efficiency.

Figure 6 summarizes measured efficiency and power density versus "effective" emitter temperature, which is defined in terms of the photon flux impinging on the voltaic cell. For example, a quoted temperature of $900^{\circ} \mathrm{C}$ corresponds to a photon flux equal to that at the surface of a blackbody emitter with emissivity of 1.0 at $900^{\circ} \mathrm{C}$. Emissivities lower than 1.0, and/or converter geometries that reduce the view factor, can lower the effective photon flux and temperature, reducing efficiency and power density.

Figure 6 presents measured overall conversion efficiencies versus emitter temperature. The measured spectral efficiency for these experimental conditions was approximately $94 \%$. Measured conversion efficiencies ranged from $22.8 \%$ at $777^{\circ} \mathrm{C}$, to $26.0 \%$ at $1054^{\circ} \mathrm{C}$, in good agreement with analytical predictions. Also demonstrated in Figure 6 is the strong sensitivity of output electric power density to emitter temperature, as expected. The required power density of $0.4 \mathrm{w} / \mathrm{cm}^{2}$ appears achievable at $900^{\circ} \mathrm{C}$ or higher. 


\section{SUMMARY}

Analytical and experimental evaluation of voltaic energy conversion indicates that conversion efficiencies $>20 \%$, and electric power densities $>0.4 \mathrm{w} / \mathrm{cm}^{2}$ are achievable at emitter temperatures below $900 \mathrm{C}$. There appears to be growth potential in this area, given the unoptimized nature of the voltaic materials used, either by improvement in the quantum efficiency, or reduction in the dark current. Practical power generation application would involve additional losses due to convection, conduction, and generator geometric effects, that will reduce achievable efficiency and power density.

Lower temperatures offer a practical advantage for many applications because of reduced materials related issues (emitter vapor pressure, thermal stress, corrosion etc.), and because of the increased range of fossil fuels that can be employed. The limiting issue for practical voltaic converters below $900^{\circ} \mathrm{C}$ is the required power density, which is a strong function of temperature. The specific application will determine the minimum practical emitter temperature. 


\section{REFERENCES}

1) A Fahrenbruch and $R$ Bube, Fundamentals of Solar Cells, Academic Press 1983.

2) K Seeger, Semiconductor Physics, Springer Series, 1982 .

3) R Swanson, Silicon Photovoltaic Cells in TPV Conversion, EPRI Research Project ER-1272, 1979.

4) $R$ Demichelis and $E$ Minetti-Mezzetti, A Solar Thermophotovoltaic Converter, Solar Cells 1 (1979/80) 395-403.

5) A Day, w Horne, M Morgan, Application of the Gasb cell In Isotope-Heated Power systems, Proceedings of the 21 st IEEE Photovoltaic Specialists Conf, May 1990.

6) H Hofler, H Paul, W Ruppel, P Wurfel, Interference Filters for Thermophotovoltaic Solar Energy Conversion, Solar Cells 10 (1983) 273-286.

7) L Woolf, Optimum Efficiency of Single and Multiple Bandgap Cells in Thermovoltaic Energy Conversion, Solar Cells, 19, December 1985 .

8) A Rose, Photovoltaic Effect Derived From the Carnot Cycle, Journal of Applied Physics, Vol. 31 No. 9, 1960. 


\title{
FIGURE 1
}

Thermo Voltaic Concept

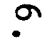

Blackbody

Heat In Spectrum

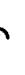
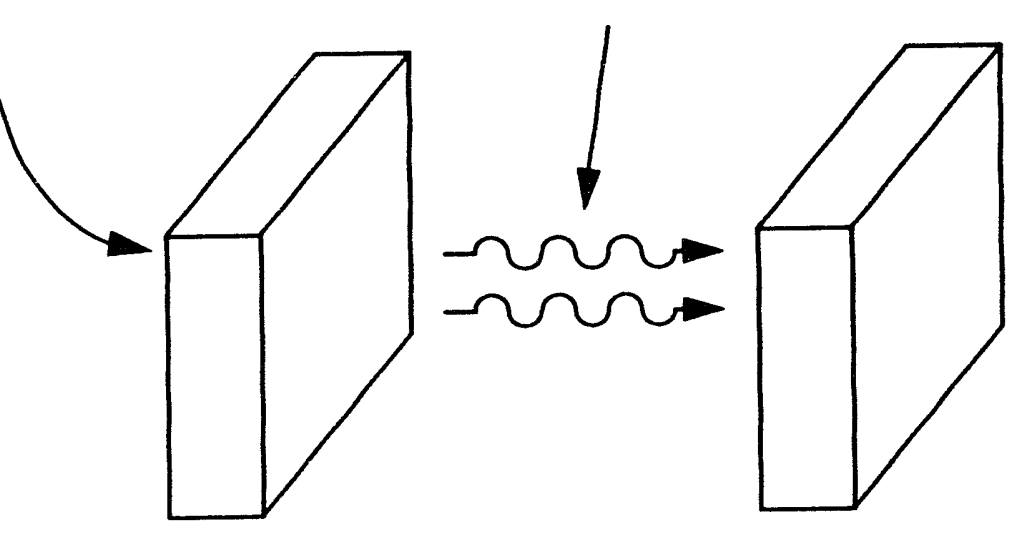

Filtered

Spectrum

Electric Power

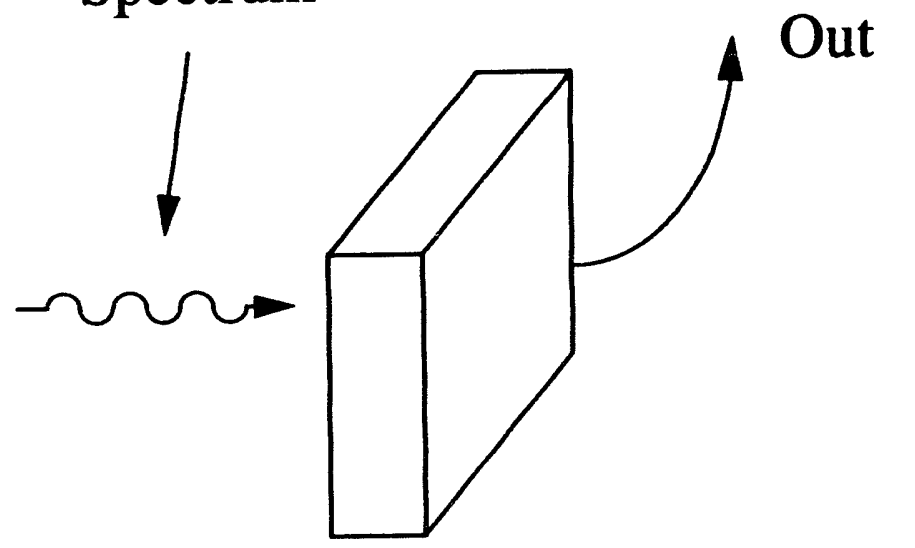

营
$\vdots$
$\vdots$
$\vdots$
0

\author{
Thermal \\ Radiation \\ Emitter
}

Spectral

Control

Device
Voltaic

Cells 
FIGURE 2

Predicted $900^{\circ} \mathrm{C}$ Voltaic Cell Performance

(Spectral Efficiency $=90 \%$ )

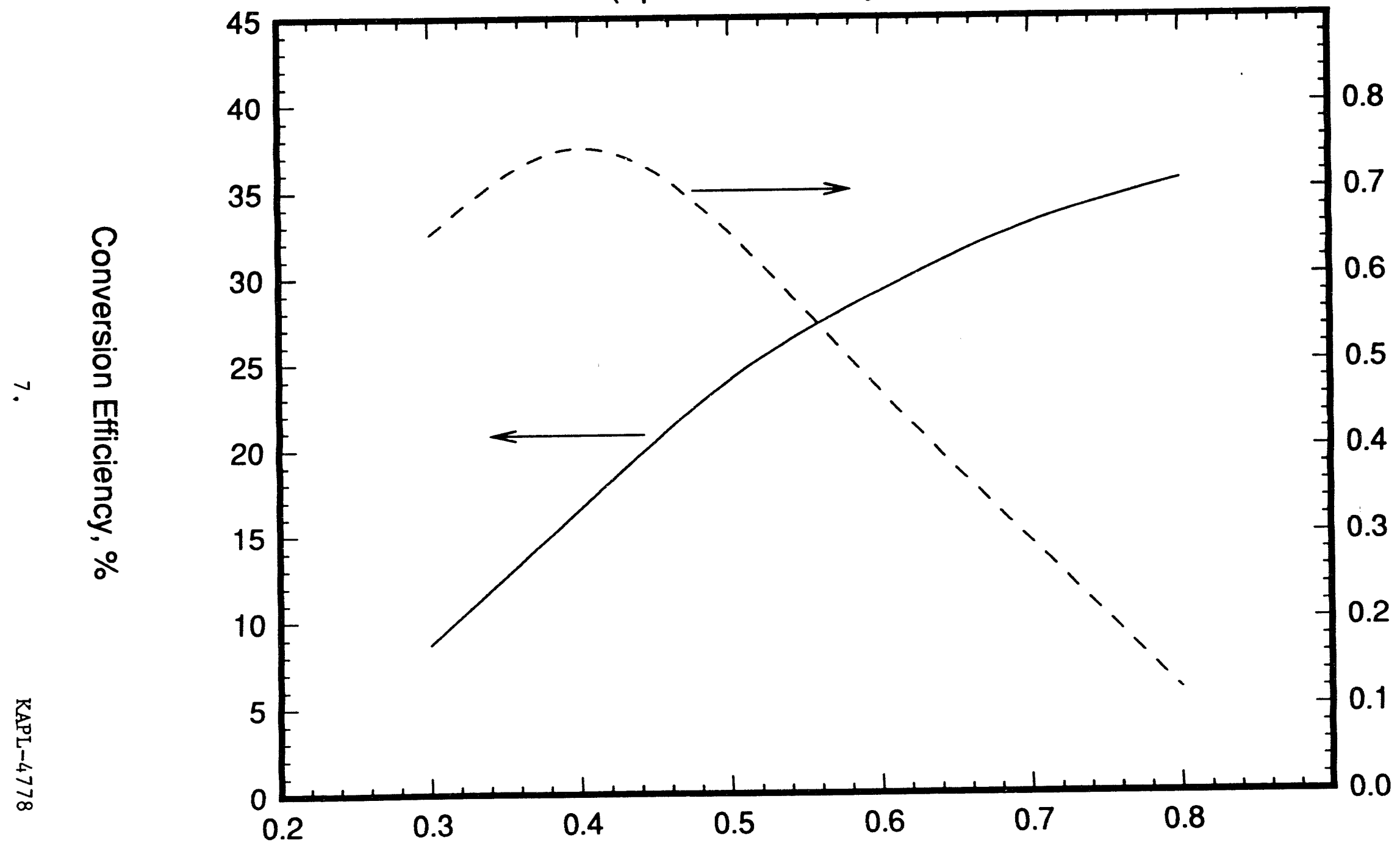

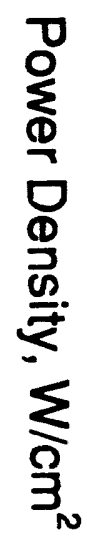

Bandgap, eV 


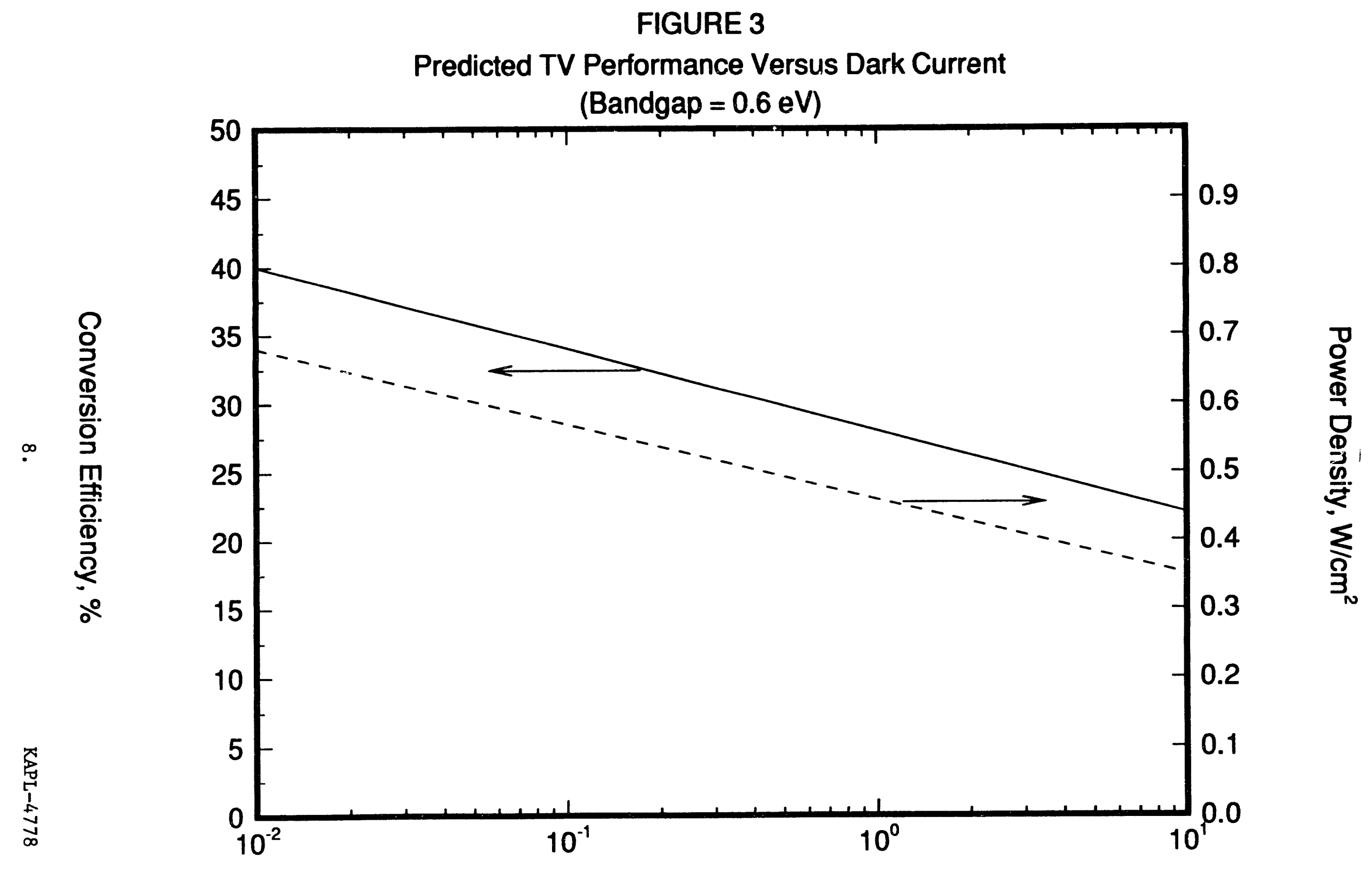

Factor on NREL Dark Current Correlation 
FIGURE 4

Predicted TV Performance Sensitivity To Spectral Control

$($ Bandgap $=0.6 \mathrm{eV})$

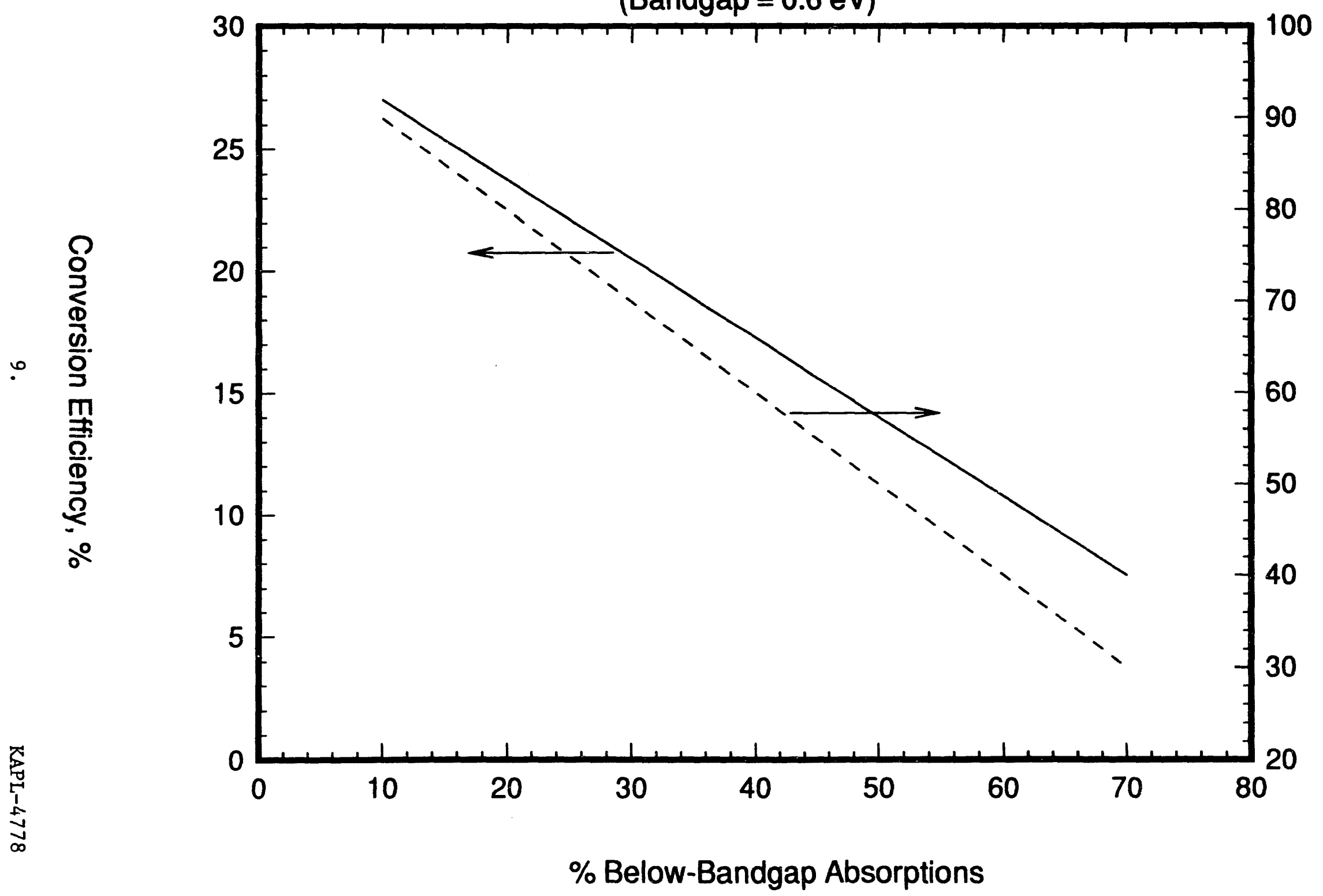

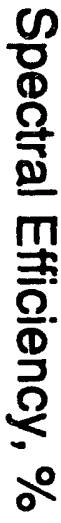




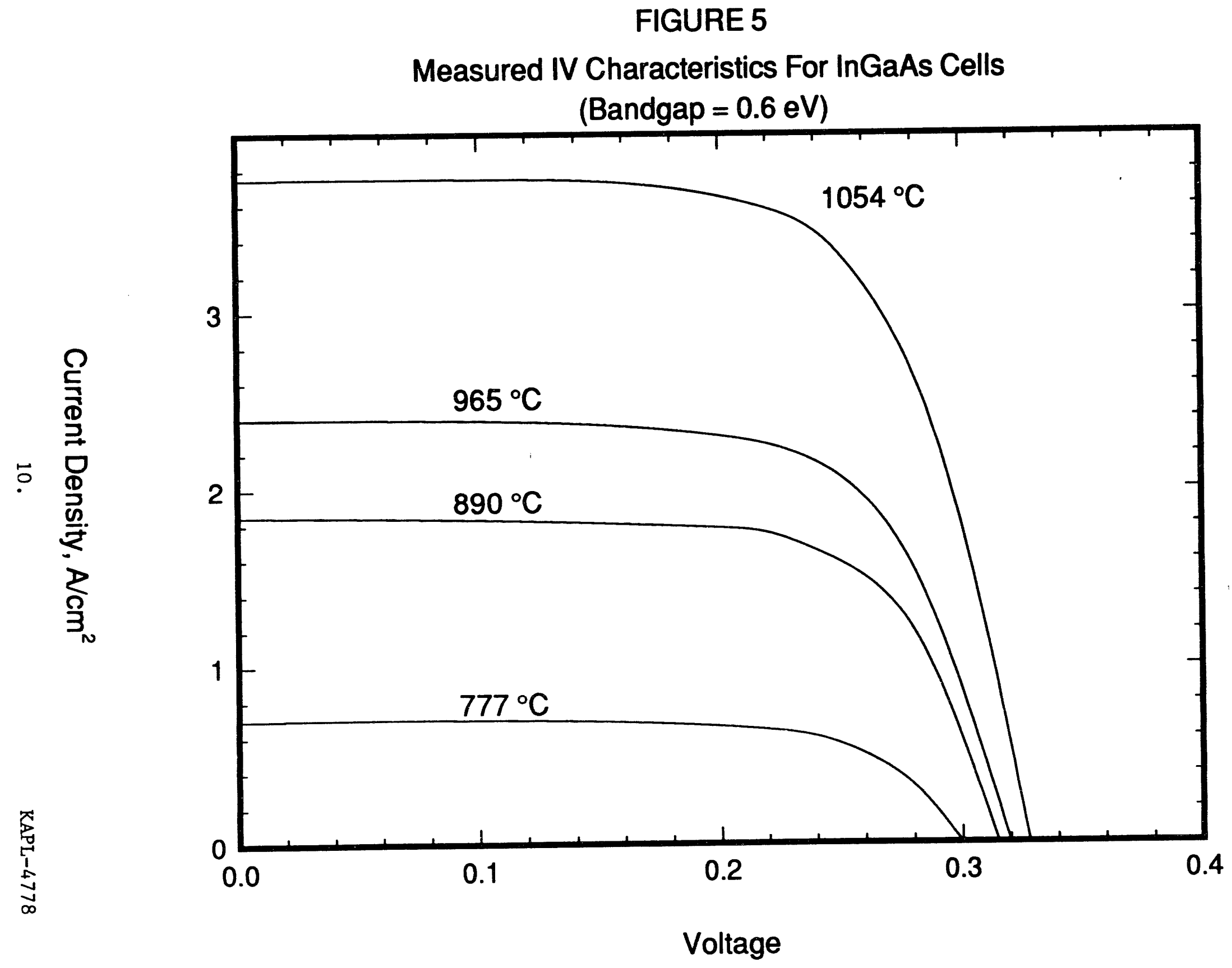




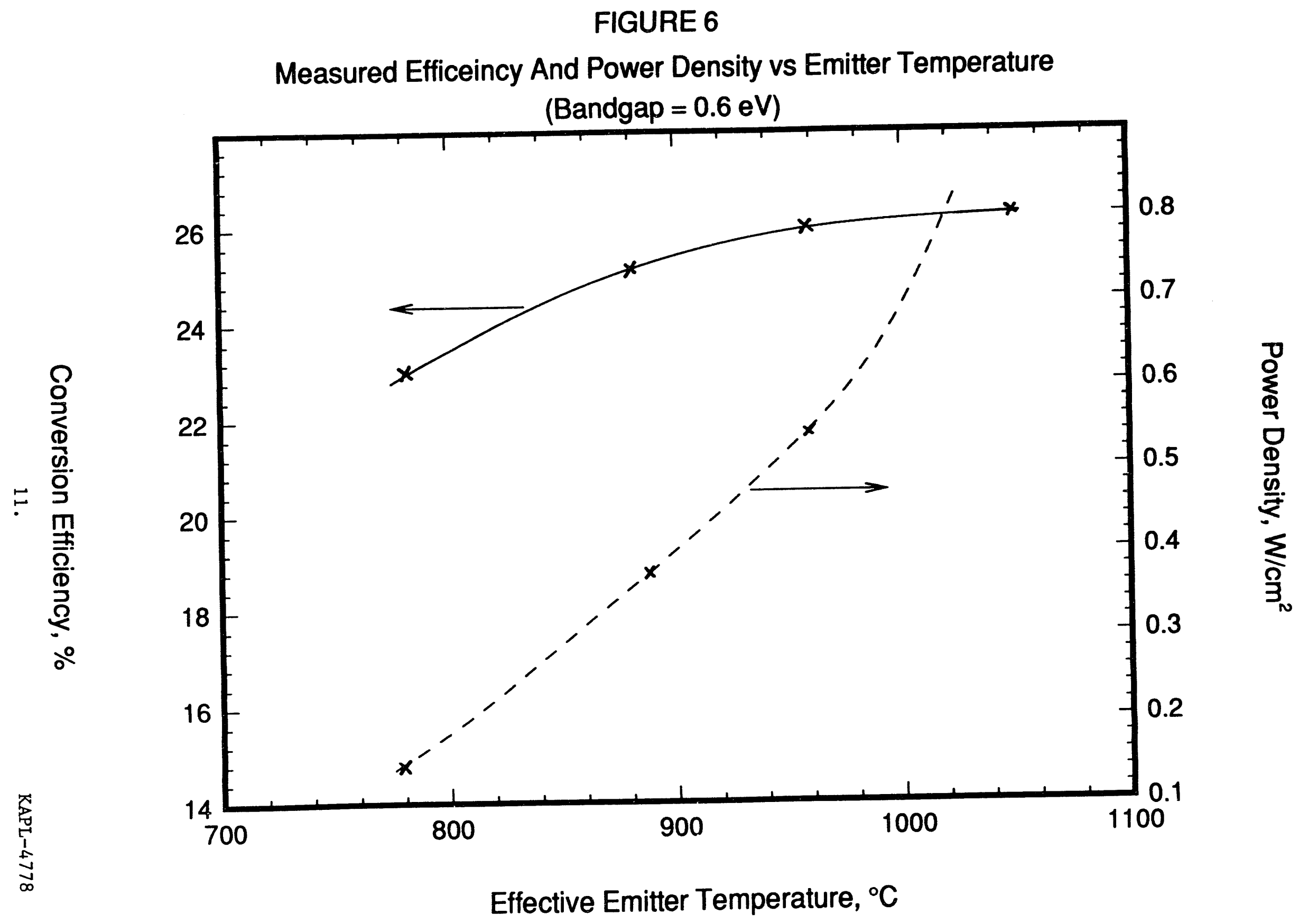



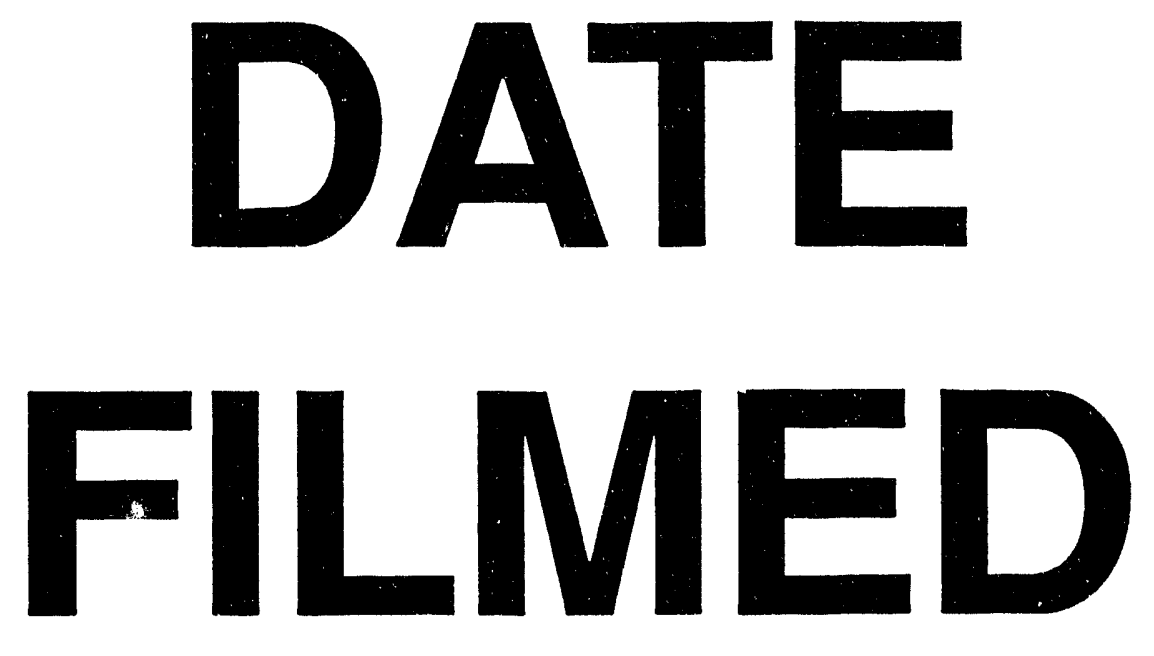

$8 / 11 / 94$
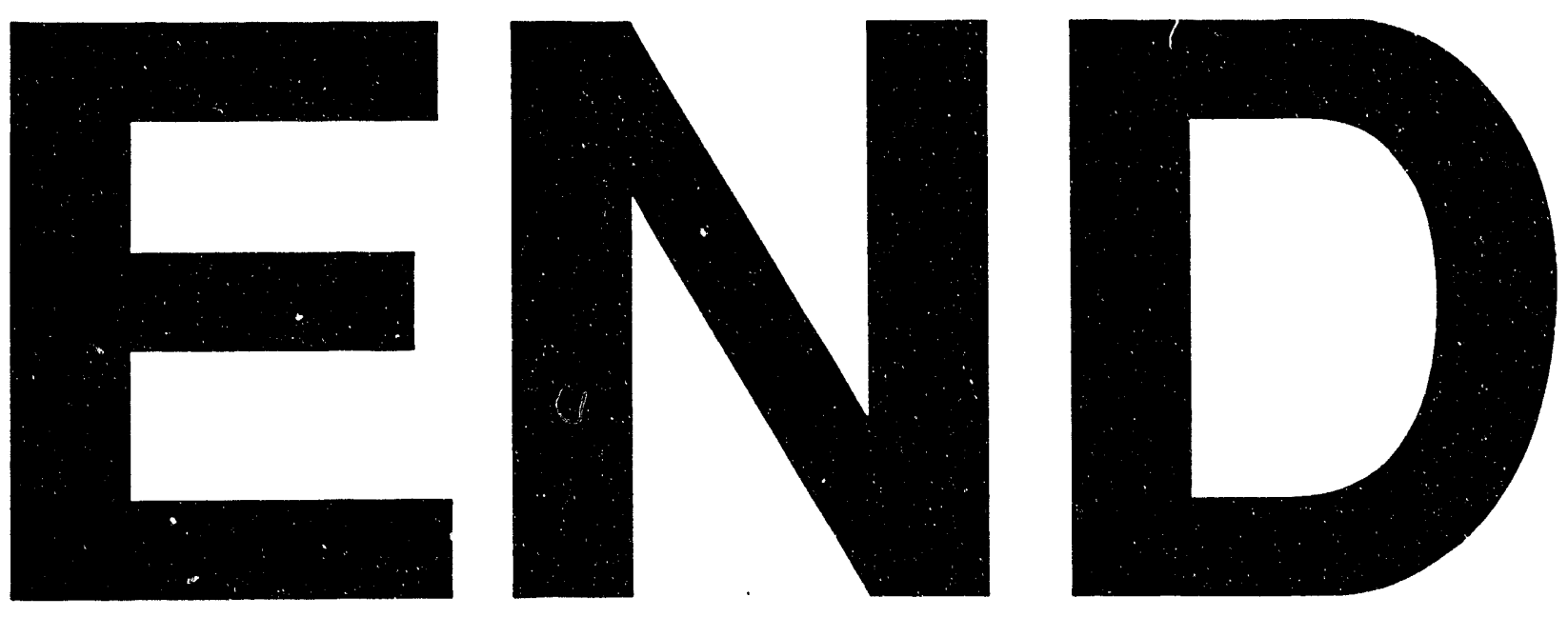
